\title{
Malaysian accounting: an inquiry into the struggle, the crisis, and the future
}

\author{
Hasri Mustafa ${ }^{1, *}$ \\ ${ }^{1}$ Department of Accounting and Finance, 43400, Universiti Putra Malaysia,
}

\begin{abstract}
Are we satisfied providing of what accounting has provided? How many books about accounting and accountability have we read and forgotten the instant we finished reading them? What difference they have made then? Will readers understand the deepest emotion of the texts? So many years have passed and many witness what happen to Malaysian history to accounting field was left unnoticed. Attempt to answer the questions will subsequently implicate the conditions of theorizing accounting based upon an inquiry into Malaysians own struggle, crisis and future prospect. The aim of the study is to encourage accounting researchers, especially Malaysians, to view accounting with responsibility, answerability, blameworthiness, liability, and other terms associated with the expectation of account-giving.
\end{abstract}

\section{Introduction}

Does it really matter who were native and who were not to a particular territory (or State) to the field of accounting? The school systems and universities leave no comprehensive discussion in regard to accounting knowledge. Pre-independent Malaysia literature in respect to social conceptions and groupings of races that define essential types of individuals has received rather reluctant to the attention of Malaysian accounting scholars. Prior to the making of the State, Malaysia was ruled by a number of kingdoms and colonial periods. Essentially, Chinese and Indians comes to Malaysia from a set of unsystematic organisation where legislations to regulate them were from colonial vision of 'divide and rule'. This is particularly problematic from the context of Malaysia historical setting which was simply irrelevant to many young accounting students and lecturers. Most research in accounting see accounting from the 'perfect' market condition that is based on utilitarian in function.

Interestingly, scholars who studied accounting found the imperfect market condition is actually a good point of departure for a good research [1]. Because history is the study of the past, particularly how it relates to the memory, discovery and collection, crisis, fighting and the other struggling are invaluable for the very basis of inquiry. In accounting, a good illustration of exposing the faulty of ideal market may be found in the Enron case of 'cooked the books' $[2,3]$. Our failure to notice early of Enron's predicament was because

* Corresponding author: hasyie@upm.edu.my 
accounting researchers correspond to Enron within the consciousness of the limited generalised observations, such as in the words 'success', 'measure', and 'earnings per share' [4]. A research on these identified independent variables may popular to some scholars, but they are limited in providing a better understanding of accounting knowledge. If this world accounting research community is to survive, the current disinterest of researching accounting chronicles and old historical account of events would be enlarged and many will still see accounting in the orderly form.

Accounting is primarily a conception about civilization and organized society, even though accounting was primarily theoretical. The elaboration about the diversity of the society is critical so that efforts in discussing, arguing, thinking and contemplating of accounting knowledge are obtained at best. Regarding the three main groups of Malays, Chinese and Indians, they have influenced continuous debates amongst historians from many spheres: politics, economics, ideology and religion [5, 6, 7, 8, 9]. Malaysia's plural society has provoked exploration of topics such as the State, the regime, the capitalists, the nationalists, the enactment and the self-accountability as designated contexts within which the dominant theorising of motivation, contract, production, agency and organisation of Malaysians are discussed. The failure to include them, bring us no sufficient condition to examine matters of power and conflict hence avoiding critical discussion in accounting literature.

\section{The spirit}

In July 2011, I started with my first plan of producing such study. I wanted to produce a study that would contribute to the understanding of accounting in Malaysia but based on a collective portrait of national quarrels, riots, communism, political movement and the establishment of social justice and democracy societies from the very first to the newest Malaysian historical settings. I hope the historiography would contain a sound reflection on theoretical conception on accounting in a clearer and weightier presentation than my doctoral thesis. In so doing, although some of the data was from my PhD thesis, most contents are new. I had a feeling the significance of the study lies, besides events and new settings, with the effort to bring the historiography to which a social mix of suggestions would be invited. As such, I required more open and rational dialogues or exchange of views.

Fortunately, on 1 September 2011, with a strong recommendation from my Head of Department and Dean, I was granted to carry my sabbatical leave for that works for six months in Christchurch and three months in London, the places where I was not a student but would meet me with a number of accounting scholars. If I were to retrospect, I am glad that I had opportunities to discuss with friends, colleagues and scholars about how to engage Malaysia in a more informative form within its own proper frame of reference. Beginning in Australia, a country with a second-highest human development index globally ${ }^{2}$, I was introduced in my PhD to 'new', 'alternative' and 'critical' views of accounting at a broader social level. Then, in Britain, where the rise of nationalism and movement is remarkably dramatic, I came to realise that methodology alone is too situation-specific to research so to be bound by researcher's own avowed aspirations. Different approaches may necessary to attain a full description of the world. Later in New Zealand, I took an unpaid leave from 1 August 2012 to 31 May 2015. I felt that a passionate desire for entirely accepting liberalisation revolution as the validity claim for the so-called critical accounting is not really helpful. I believe Malaysia's growth, inasmuch as New 
Zealand's agricultural territorial-in-chief, is powered by its own characteristics and therefore somehow individualistic.

I should add here that I find myself constantly asking: to which part of the world I could know better about Malaysia? Although there were a number of historical details I gained from their libraries, history is not only the discovery but also the recovery. Malaysian history is not out there, it is in the common sense ${ }^{3}$ of Malaysians. Admittedly, in Malaysia not many references in accounting I could follow. Just look at the other ancient kingdoms such as ancient Greek [10, 11], Roman [12], India [13, 14] Mesopotamia [15, 16, 17, 18], and in the early Muslims accounting especially the Middle and Near East Countries [19, 20, 21]. With their publication number increases I afraid the younger generation of accounting would have developed tastes in non-Malaysian history, leaving the Malaysian history into separate discipline. A new generation like me has to go out to get the idea of Malaysian accounting from the philosophy of internationalism in the foreign material and spiritual culture. There was bread and maybe sugar in the West, or any other places around the world, but then the flour was gone. There is no need here to recapitulate in any detail the arguments that I have received with my non-Malaysians discussants but what in Malaysia do I have out there?

It is from this frame of references I develop the contents of this study. The next section includes the conditions and characteristics of what Malaysia has come. It contains a base of support in what I call the societal program of Malaysia from the period of Malay States, Malaya, Malaysia and 1-Malaysia. It recognises 'struggle for survival', 'crisis of growth' and 'future of ethical institutions' views from the actual history and nature of Malaysia that have potential contribution to the conception of accounting and the development of accounting theory. Malaysia had wealthy resources, but there were the reasons for conflicts and political differences. To escape these characteristics is to ignore the common production of Malaysia. There seems little reason to deny accounting conception a glimpse of this aspect. The final section discusses the theoretical implications and the limitations of the research as a whole.

\section{An inquiry into Malaysian accounting}

Malaysian Dilemma shows that although Malaysia's plural society is in principle universal, they involve the individual struggle and an optimisation directed towards the future of each ethnic group. In 1957, Rupert Emerson, a Harvard political scientist, made these remarks about Malaysia: '[t]he country is a 'perfect example of the plural society'. The different peoples have in common only the fact that they live in the same country. In race, religion, language, culture, economic interests...their outstanding characteristic is not unity but profound diversity' [22, p. 5].

The key points; 'plural society' and 'race, religion, language, culture, economic interests', which Emerson underscored, are the landmarks of Malaysia's societal program. In principle, almost any discussion on Malaysia's societal program must be structured within the three main ethnic groups: Malays, Chinese and Indians, who all tend to remain more dominant than other ethnic groups. These three main groups are the ones to which Emerson refers 'their outstanding characteristic is not unity but profound diversity'. The definition of Malays, Chinese and Indians suggests that the three dominant groups are heterogeneous in the same sense that Malaysians at large are. According to Malaysian historian Khoo Kay Kim, 'in the case of the Chinese and Indians, the heterogeneous character of each group [is] derived from the land of its origin. This was reinforced in the 
land of its adoption' [23, p. 251]. To Khoo, 'no simple explanation can be given for this. But one plausible explanation is that their influence was thwarted by the fact that they had to operate in a plural society which was also under colonial rule' [24].

Now, how then am I to speak about accounting in response to the above accounts? Over its short history, Malaysia has experienced dilemmas that were initially casual but were soon to be cumulative across social capital, ideology and basic material needs. All these factors have placed accounting into the much wider context that I had ever anticipated. For I see them as genuine and sincere. They are the real battlefields for Malaysians. They offer me to see accounting on societal program from the imperfect market condition as point of departure.

\subsection{A State and the struggle for survival}

Table 1 summarises my observations on the factors cited above but includes the other more critical contents about the first production (construction) of today's Malaysia. The table I use to restrict my accounting journey from the references of monarchy, wars, colonial powers, and labour capital for international trade and local production. I would call these references the struggle for survival period as the events involve Malays, colonies and merchant-migrants into the state of continuing to live, typically in spite of an accident, ordeal, or difficult circumstances.

Table 1. Societal program of the production (construction) of Malaysia from the 'struggle for survival' view

\begin{tabular}{|l|l|}
\hline Years & Struggle for survival \\
\hline $\mathbf{1 3 5 1}-\mathbf{1 7 6 7}$ & $\begin{array}{l}\text { A tributary gold and silver tree from Malay State Rulers of Patani, Kedah, Kelantan, } \\
\text { Trengganu and Perak } \\
\text { to Siam Kingdom }\end{array}$ \\
\hline $\mathbf{1 4 0 2}-\mathbf{1 5 1 1}$ & Malacca Sultanate empire \\
\hline $\mathbf{1 4 0 2}-$ & Malacca 'Empat pembesar Lipatan' system \\
\hline $\mathbf{1 4 1 4}-\mathbf{1 9 4 6}$ & $\begin{array}{l}\text { Malacca traders from Europe, Persia, Arabia, Tamil and other Native Indians and } \\
\text { Chinese }\end{array}$ \\
\hline $\mathbf{1 5 1 1}-\mathbf{1 6 4 1}$ & Portuguese Malacca colonisation \\
\hline $\mathbf{1 5 1 1}-$ & Indian Chetty (moneylender) System \\
\hline $\mathbf{1 6 0 6}-\mathbf{1 6 4 1}$ & $\begin{array}{l}\text { The Dutch East India Company began the campaign to destroy Portuguese power with } \\
\text { the first serious attempt being the siege of Malacca }\end{array}$ \\
\hline $\mathbf{1 6 4 1}-\mathbf{1 8 4 2}$ & Dutch Malacca colonisation \\
\hline $\mathbf{1 8 1 9}-$ & Chinese Kongsi (clan) System \\
\hline $\mathbf{1 8 2 6}-\mathbf{1 9 4 6}$ & $\begin{array}{l}\text { Malacca was governed by the British East India Company that formed part of the } \\
\text { Straits Settlements, together with Singapore and Penang }\end{array}$ \\
\hline $\mathbf{1 8 7 4}-\mathbf{1 9 4 6}$ & British Malaya colonisation \\
\hline $\mathbf{1 8 5 0}-\mathbf{1 8 8 0}$ & Tin mining industry \\
\hline $\mathbf{1 8 7 0}-\mathbf{1 8 9 0}$ & Chinese financial mining enterprise truck system \\
\hline $\mathbf{1 8 6 0}-\mathbf{1 9 1 0}$ & Indian labourer broker Kangany System \\
\hline $\mathbf{1 8 9 0}-\mathbf{1 9 4 0}$ & Rubber plantation industry \\
\hline $\mathbf{1 9 2 9}-\mathbf{1 9 4 2}$ & Rubber coupon system in Malaya \\
\hline $\mathbf{1 9 4 1}-\mathbf{1 9 4 5}$ & Japanese invasion of Malaya \\
\hline $\mathbf{1 9 4 2}-\mathbf{1 9 4 5}$ & Japanese Banana Money \\
\hline $\mathbf{1 9 4 4}-\mathbf{1 9 4 5}$ & Severe food production crisis \\
\hline $\mathbf{1 8 ~ D e c ~ 1 9 4 1 ~}$ & Malayan Peoples' Anti-Japanese Army (MPAJA) \\
\hline $\mathbf{2 3 ~ F e b ~ 1 9 5 0 ~}$ & Communist and Bukit Kepong blood incident \\
\hline
\end{tabular}




\subsection{Individualism and the crisis of growth}

Accounting is a product of the professionalism of a social class, elite group and specific agent [To name a few, 25, 26, 27]. There are examples that many of the relationships between accounting and society are accounted around these thought but, in major part, they inevitable come with disagreement to reach an understanding when necessary. One of the examples is the role played by political systems which were often accused of intervention and exaggerating contexts of reality. In the reconstruction of Malaya, these systems included the UMNO, MCA, DAP, MIC, and other political voices. These organisations reasonably pointed out the possibility that someone belonging to Malaya may participate in society but feel alienated due to their values and principles. As common for political ideologies, these movements focused upon questions of class, power, conflict and the reproduction of hierarchy and hegemony, and the concepts remained relevant until they were disrupted by notions of corruption and nepotism. Table 2 lists the significant events that deployed these central concepts from which comes the taint of political movement, ideology, and unionism. These events which were configured following the struggle for survival I refer as the crisis of growth.

Table 2. Societal program of the production (construction) of Malaysia from the 'crisis of growth' view

\begin{tabular}{|c|c|}
\hline Years & Crisis of Growth \\
\hline 1930 & MCP (Malayan Communist Party) \\
\hline $1946-1948$ & Malayan Union \\
\hline 31 Jan 1948 & The Federation of Malaya \\
\hline 1 March 1946 & UMNO (United Malays National Organization) \\
\hline August 1946 & MIC (Malaysian Indian Congress) \\
\hline 27 Feb 1949 & MCA (Malaysian Chinese Association) \\
\hline $1949-$ & Student politics in University Malaya \\
\hline 1950 & Chinese People's Action Party (PAP) \\
\hline 24 Nov 1951 & Pan-Malaysian Islamic Party (PAS) \\
\hline 1954 & $\begin{array}{l}\text { UMNO, MCA and MIC jointly formed the National Alliance (Perikatan } \\
\text { Kebangsaan) }\end{array}$ \\
\hline 31 August 1957 & The Federation of Malaya achieved independence \\
\hline 16 Sept 1963 & $\begin{array}{l}\text { The Federation of Malaya was reconstituted as "Malaysia" to include Singapore, } \\
\text { Sabah, and Sarawak }\end{array}$ \\
\hline 18 March 1966 & Democratic Action Party (DAP) \\
\hline $1963-1966$ & Indonesia-Malaysia confrontation \\
\hline 9 August 1965 & Singapore out of the union \\
\hline 24 March 1968 & Chinese Gerakan Party (Chinese Liberal Party) \\
\hline 13 May 1969 & Chinese - Malays racial riot \\
\hline 31 August 1970 & Rukunegara ("the Principles of Nationhood") \\
\hline 1971 & $\begin{array}{l}\text { The New Economic Policy (NEP) and the development of } \\
\text { Bumiputera (son of the soil) entrepreneurship }\end{array}$ \\
\hline 1983 & The 1983 Constitutional Crisis \\
\hline 1988 & Bahasa Baku (standard pronunciation of Malay Language) \\
\hline 2 Dec 1989 & $\begin{array}{l}\text { The Malaysian Communist Party formally ends } 41 \text { years of armed struggle against } \\
\text { the government }\end{array}$ \\
\hline 1993 & The loss of the Malay Rulers' immunity \\
\hline 2 Sept 1998 - & Deputy Prime Minister and United Malays National Organization (UMNO) Cases \\
\hline 4 April 1999 & Parti Keadilan Rakyat (People's Justice Party) (PKR) \\
\hline Nov 2007 & Hindu Rights Action Force (Hindraf) \\
\hline $2011-2014$ & Bersih II and III Demonstration, Blackout 505 Demonstration, Kajang Move \\
\hline
\end{tabular}




\subsection{Institutions and the future of ethical world}

Accounting is a field of ethical practices. One can recognises throughout accounting in the literature the concept of accountability that lies at the heart of accounting. There is no doubt that what has been achieved so far in accounting treatises began with this concept - about principles and guidelines that explain the account for one's actions. It is precisely embedded in the agricultural stock counting, bookkeeping, budgeting, auditing, etc. Corruption, fraud and scams are not part of accounting as it should be but a kind of deceptions of gaining an advantage through wrong accounting practice by certain individuals. For Malaysia, anticipated societal advancement must absorb the crisis of growth to incorporate an increasing accountability world order which requires transparency, answerability and other expectations of account-giving. As a developing country, growth in Malaysia should not only focus on the situation of those who are by definition positioned within the social hierarchy (which is in theory a matter of individualism such as Mahathir, Anwar, Lim Kt Siang, Karpal Singh, etc). Because Malaysians do not occupy identical or even similar positions in social contexts (i.e. 'Malays', Chinese' and 'Indians'), there is a greater chance of finding contradictory and to be antipathetic. Apparently, there is evidence when situating accounting practice within the politics and conflicts of individualisms, individualism has done little to encourage explain critically the unintended consequences of human actions in institutional contexts. There is evidence in accounting literature that the quality of institution offer sufficient conditions to examine matters of power and conflict hence including critical discussion in making sense of the past and to explain why there is coherence to such practices and proceedings ${ }^{4}$. Table 3 contains significant events that envisage different signs of ethical institutions that came into being as a result of modernisation. I would call these events the future of ethical institutions for they produce a variety of compounds for accountability elements.

Table 3. Societal program of the production of Malaysia from the 'future of ethical institutions' view

\begin{tabular}{|c|c|}
\hline Years & Future of Ethical Institutions \\
\hline 4 March 1993 & Skim Perbankan Islam (SPI) (Islamic banking windows) \\
\hline 1 May 1997 & The National Shariah Advisory Council (SAC) on Islamic Banking and Takaful \\
\hline $1997-1998$ & Economic crisis \\
\hline Sept 1998 & Ringgit was pegged at 3.80 to the US dollar value \\
\hline 1998 & The establishment of Corporate Debt Restructuring Committee (CDRC) \\
\hline June 1998 & The incorporation of Pengurusan Danaharta Nasional Berhad (Danaharta) \\
\hline $\begin{array}{l}\text { Sept } \\
1998\end{array}$ & $\begin{array}{l}\text { Malaysia's exchange rate regime pegs the Ringgit at } 3.8 \\
\text { to the US dollar }\end{array}$ \\
\hline 17 April 1999 & The KLSE Syariah Index \\
\hline 12 Dec 2001 & $\begin{array}{l}\text { The Malaysian Accounting Standards Board (MASB) on the Presentation of } \\
\text { Financial Statements of Islamic Financial Institutions? }\end{array}$ \\
\hline $\begin{array}{l}\text { April 2000 - } \\
\text { March } 2003\end{array}$ & The merger of banks and financial institutions \\
\hline Dec 2004 & $\begin{array}{l}\text { The Guidelines on the Governance of Shariah Committee for the Islamic Financial } \\
\text { Institutions }\end{array}$ \\
\hline 2005 & The propagation of Islam Hadhari \\
\hline
\end{tabular}

${ }^{4}$ Some accounting scholars view that there are flaws in the mode of individualism for the critical analysis of accounting practice. For example, Carruthers in his review of Walter Powell and Paul DiMaggio's 1991 edited volume: The New Institutionalism in Organizational Analysis concludes that 'one must reject the assumptions of methodological individualism and individual rationality' [28]. 


\begin{tabular}{|l|l|}
\hline Jan 2009 & 1Malaysia Development Berhad \\
\hline Sept 2010 & The propagation of 1-Malaysia \\
\hline 7 Jan 2010 & 1Malaysia Clinic \\
\hline Jan 2010 & $\begin{array}{l}\text { 1Malaysia Poverty Eradication } \\
\text { (1AZAM or Akhiri Zaman Miskin 1Malaysia) }\end{array}$ \\
\hline 1 June 2011 & 1Malaysia Training Scheme (SL1M or Skim Latihan 1Malaysia) \\
\hline Dec 2011 & 1Malaysia People's Aid (BR1M or Bantuan Rakyat 1Malaysia) \\
\hline 2 July 2012 & KADS1M or Kad Diskaun Siswa 1Malaysia \\
\hline March 2015 & SR1M or Sim Kad Rakyat \\
\hline July 2015 & Accountability issues on 1Malaysia Development Berhad \\
\hline
\end{tabular}

\section{Theoretical implications and the three-transformative event of accounting}

So what are the ways to research? Would the above kind of ontological view of viewing accounting work for me? For the moment, let us simply emphasise the following questions: How much can the struggle for survival, the crisis of growth and the future of ethical institutions contribute to accounting theory? What kinds of accounting can I introduce from this three-transformative event? Below, via Table 4, I respond the questions concerning on how to analyse Malaysia's societal development as I have defined above. Table 4 incorporates the three-transformative event. It consists of three main columns which are to be denoted in respect of the societal program of concern; 'struggle for survival', 'crisis of growth', and' future of ethical institutions'. For each of them, the societal program flows following a genealogical analysis from the period of Malay States to Malaya, Malaya to Malaysia and Malaysia to 1-Malaysia. On this arrangement, a moment between the hierarchical power relation between those who used and employed the sources of raw materials and human forces, the organisers and regulators, and those who are thus concerned the moral rights embedded in the principles of economic, can be seen. In the middle row, themes such as 'the State", 'the regime', 'the capitalists', 'the nationalists', 'the enactment' and 'the self-accountability' are put not in specific to certain perspective of the societal program as by no means they can be isolated. The next row contains the said perspectives of the societal program. Note that the lines of them are not parallel with those of the organisations, but on the whole order in which the societal program become unified, runs from episode to episode, from climax to climax.

Table 4. Theoretical interpretation of accounting in accordance to the societal program in the production of Malaysia

\begin{tabular}{|l|l|l|l|l|}
\hline \multicolumn{3}{|l|}{ Readings: The State, the regime, capitalism, nationaliss, the enactment of self-accountability } \\
\hline Struggle for survival & Crisis of growth & \multicolumn{2}{|c|}{ Future of ethical institutions } \\
\hline $\begin{array}{l}\text { Accounting is } \\
\text { read as a field in } \\
\text { which its } \\
\text { operation is }\end{array}$ & $\begin{array}{l}\text { Accounting is read as a field in } \\
\text { which its operation is essentially } \\
\text { characterised by political } \\
\text { survival in which its parent and } \\
\text { the ruling party impose a } \\
\text { promote hegemony }\end{array}$ & $\begin{array}{l}\text { Accounting is read as } \\
\text { a field in which its } \\
\text { operation is } \\
\text { essentially } \\
\text { characterised by the } \\
\text { accountability } \\
\text { concepts derived from } \\
\text { Shariah law and } \\
\text { commitment to } \\
\text { Fardhu Kifayah }\end{array}$ \\
$\begin{array}{l}\text { essentially } \\
\text { characterised by } \\
\text { the notion of an } \\
\text { utopian State } \\
\text { ideology to } \\
\text { promote stability } \\
\text { and security }\end{array}$ \\
\hline \multicolumn{2}{|l|}{ Types } & Wealth & Momentum accounting & Force accounting \\
\hline
\end{tabular}




\begin{tabular}{|c|c|c|c|}
\hline & accounting & & \\
\hline $\begin{array}{l}\text { Societal } \\
\text { Program }\end{array}$ & $\begin{array}{l}\text { Struggle for } \\
\text { survival }\end{array}$ & Crisis of growth & Future of ethical institutions \\
\hline Conception & Trust, security & Political, hegemonic & $\begin{array}{l}\text { Religious: Shariah law, Fardhu } \\
\text { Kifayah }\end{array}$ \\
\hline Dimension & $\begin{array}{l}\text { Wealth } \\
\text { magnitude - } \\
\text { 'what' } \\
\text { amount }\end{array}$ & $\begin{array}{l}\text { Wealth change - 'how' to deal } \\
\text { with }\end{array}$ & $\begin{array}{l}\text { Change of wealth change - 'why' } \\
\text { dialectical }\end{array}$ \\
\hline Scope & $\begin{array}{l}\text { Writing and } \\
\text { managing } \\
\text { money }\end{array}$ & $\begin{array}{l}\text { Rigid accounting control and } \\
\text { human capital }\end{array}$ & $\begin{array}{l}\text { Specialist accountant: innovation } \\
\text { capital, intellectual property, } \\
\text { intangible asset }\end{array}$ \\
\hline $\begin{array}{l}\text { Form of } \\
\text { accounting }\end{array}$ & Bookkeeping & Income generator & Auditor and governor \\
\hline Centre & $\begin{array}{l}\text { Responsible } \\
\text { centre }\end{array}$ & Cost centre & Accountability centre \\
\hline Problem & $\begin{array}{l}\text { Different } \\
\text { units have } \\
\text { own self- } \\
\text { definition }\end{array}$ & $\begin{array}{l}\text { The unhealthy company will be } \\
\text { absorbed by the healthy one }\end{array}$ & $\begin{array}{l}\text { No previlaged accounting } \\
\text { framework. Not accounting is also } \\
\text { accounting }\end{array}$ \\
\hline Motive & $\begin{array}{l}\text { Action at a } \\
\text { distance, } \\
\text { translate } \\
\text { wealth into } \\
\text { observable } \\
\text { and } \\
\text { measurable } \\
\text { categories }\end{array}$ & $\begin{array}{l}\text { Maintaining hegemony of the } \\
\text { preferred monarchy }\end{array}$ & Corporate accountability \\
\hline
\end{tabular}

\section{1 'Struggle for survival' - Wealth accounting}

Ijiri refers 'wealth accounting' as the first dimension for the administration of the magnitude of wealth and wealth composition, with accounting variables that are set apart as net wealth (equity) and liabilities (sources of capital), or as assets (uses of capital) [29]. Accounts of this dimension are meant to emphasise the anticipation of the wealth magnitude and composition of 'what' amount. Cause and effect rationalization in this accounting treatment is very important as it explains the objective and the struggle of a State. Accounting is aimed at achieving a new equilibrium for the State. It started with an exploration of a sense of "unsatisfactory" which is linked with beliefs reflecting negative feelings about people and their wealth, in particular between the poor and the rich, between the sons of the soil (Bumiputera) and the Immigrants. Exploring this institutional setting requires that we think about trust and security.

Writing and managing of money are theorised with bookkeeping to represent 'accounting at a distance', allowing the materials to congregate mobility, stability, collectability, examinability, and combinability [30, 31, 32, 33]. They should become centers of integrity and trust. Centers of integrity and trust, as opposed to "cost centers," develop in an organisational village where there are fences and differences between households but plenty of transactions across them [34, p. 102].

The accountants' functions are plainly constrained to oversee the characteristic of combinable inscriptions and "emerge [when] if the report is seen as illogical, the figures too big, printing problem, and errors" . Accountants have limited freedom and are exposed to the observable and measurable categories. 


\section{2 'Crisis of growth' - Momentum accounting}

A discussion of the Federation of Malaya now turns to the vexed issue of political language in a more contemporary setting. It presents the interpretation of accounting in intellectual outlook in a vocabulary of political survival, in the virtue of 'crisis of growth' societal program. Within the political crisis, I view accounting as a locus of power, in a revolutionary or momentum form, and in the concept that may oppose public rationality, in the conception of political and hegemonic. It is from this perspective that the context of accounting is not similar to that in the struggle for survival. Accounting is bound to have priority which is based on maintaining the rules of the game of the established community. The result of this process is a condition of the second dimension for the administration of the change in magnitude of wealth (the first dimension), with accounting variables that are set apart as cost (outflows) and income (inflows) of what Ijiri terms 'momentum accounting' [35].

Accounts of this dimension are not meant to emphasise the anticipation of the wealth magnitude and composition of 'what' amount but the wealth change which is explained by its 'how' to deal with. This consideration produces the rigid accounting control by individualists, especially cash and extra remuneration, in order to make sense of the preference of the preferred monarchy. The conception of accounting is acting essentially in the momentum of the political scenario from the particular intellectual context peculiar to movement, ideology, and union since Malaya. The problem of 'momentum accounting', in a nutshell, is that when it comes to the question 'who is the subject of scarification?', the unhealthy company will be absorbed by the healthy one.

\subsection{Future of ethical institutions - Force accounting}

When examining the production of Malaysia, the discussion should not end to various accounts of the relation between the concepts of struggle for a survival and the political right only. There were clearly a number of early law codes, embodied in particular inherited principles of colonists, which will be seeing inaccurate, too communitarian and lack justice. The concept of 'divide and rule' by colonists since the duration of the old Malay States, then Malaya, until the current Malaysia State are found fundamentally to contain racial characteristic. Political and capitalist theory carried a number of 'social justice questions' to human being.

In the modern presence, fortunately there are concerns to capture the many formulations of the more ethical perspective in Malaysian laws and enactments. More educated Malaysian people see ethics should become the essence which cannot be sacrificed. However, none of this is likely to happen in sincere if communitarian and personalist socialism are the condition for the ethical consideration. Religion should be the source for the idea. Ethics must be institutionalized through religion to include all practices and structure of dominations. This includes accountants, auditors, and council members. The interpretation of them and their system are therefore should be a reference to accounting. Religious auditor or in Islamic Bank is the correct example. Their jobs are to promote the ethical institution and actualization of morale that make a bank worthy of esteem and respect. The taking of riba (usury), gharar (speculation) and the investing and financing of certain activities, such as, among others, the production of liquor, pork, tobacco; the entertainment activities of brothels and night clubs; and the distillery and gambling houses is neither conditional nor optional. Religious auditor is responsible for the well being of the Malaysian society and the money invested is counted to the productive business venture not to meet personal accumulation wealth. From this standpoint, accounting is set apart to 
administer internal and external forces. At this stage, accounting is in the third dimension for the administration of the change of capacity to acquire new wealth (the second dimension). Theoretically, this Ijiri calls 'force accounting' as accounting is on force statements that include impulse and action [36]. Innovation capital, intellectual property, intangible asset such as Mudharabah, Musharakah, Wadiah, Bai Bithamin Ajil, Ijarah and Wakalah are the product from this kind of accounting. There could be more specialist accountants.

In the process of transforming Malaysia to 1-Malaysia, the key is then equality and nondiscrimination. As Islam prohibits injustice, exploitation, discrimination, and all sort of unfairness, accounting should therefore be applicable to all and should be seen to fundamentally consistent to seek for the best for the society. The problem of 'force accounting' is that 'not accounting' could also a form of accounting too. As such, although specialists are being promoted, there is no previlaged accounting framework however for accountant in the name of accountability. Religious auditor, for example, is accountable not only with the task but with the 'no task' they do since the implication of doing and not doing is very big - to customers, Islamic banking industry, and society at large. Because accounting responds to accountability at issue, matters are divided into necessary, recommended, permissible, dislike or forbidden in the name of corporate accountability.

\section{References}

1. O. Marnet, History repeats itself: The failure of rational choice models in corporate governance. Critical Perspectives on Accounting 18, 2 (2007)

2. C. R. Baker, R. Hayes, Reflecting form over substance: the case of Enron Corp. Critical Perspectives on Accounting 15, 6-7 (2004).

3. N. Chabrak, N. Daidj, Enron: Widespread myopia. Critical Perspectives on Accounting 18, 5 (2007)

4. R. J. Craig, J. H. Amernic, Enron discourse: the rhetoric of a resilient capitalism. Critical Perspectives on Accounting 15, 6-7 (2004)

5. A. Gurowitz, Migrant rights and activism in Malaysia: Opportunities and constraints. The Journal of Asian Studies 59, 4 (2000)

6. K. S. Jomo, Whither Malaysia's new economic policy? Pacific Affairs 63, 4 (1991)

7. Ye Lin-Sheng, The Chinese dilemma (New South Wales, East West Publishing Pty Ltd., 2003)

8. R. S. Milne, Malaysia-beyond the new economic policy. Asian Survey 26, 12 (1986)

9. Shukor Omar, Malay business: Revivalism through entrepreneurship (Kuala Lumpur, Pelanduk Publications, 2006).

10. G. de Ste Croix, Greek and Roman accounting, in A. C, Littleton, B. S. Yamey (eds.), Studies in the history of accounting (London, Sweet and Maxwell Limited, 1956)

11. G. de Ste Croix, The class struggle in the Ancient Greek World from the Archaic age to the Arab conquests (Gerald Duckworth and Co. Ltd. London, 1981)

12. R. H. Macve, Some glosses on Greek and Roman accounting, in B. S. Yamey, R. H. Parker (eds.), Accounting history: Some british contributions (Oxford, University Press, 1994)

13. B. L. Nigam, Bahi-Khata, The pre-Pacioli Indian double-entry system of bookkeeping. Abacus 22, 2 (1986)

14. M. E. Scorgie, Indian imitation or invention of cash-book and algebraic double-entry. Abacus 26, 1 (1990)

15. G. Vollmers, Accounting historiography using ancient sources: Problems and rewards, in R. Fleiscliman, V. Radclifle, P. Shoemaker (eds.). Doing accounting 
history: Contributions to the development of accounting thought (Durham, Duke University Press, 2003)

16. R. Mattessich, Prehistoric accounting and the problem of representation: On recent archaeological evidence of the Middle East from 8000 B.C. to 3000 B.C. Accounting Historians Journal 14, 2 (1987)

17. R. Mattessich, Recent insights into Mesopotamian accounting of the 3rd millennium B.C - Successor to token accounting. Accounting Historians Journal 25, 1 (1998)

18. R, Mattessich, The beginnings of accounting and accounting thought: Accounting practice in the Middle East (8000 B.C. to 2000 B.C.) and Accounting thought in India (300 B.C. and the Middle Ages) (New York, Garland Publishers, 2000)

19. O. A. Zaid, The historical and theoretical framework of financial accounting in the muslim society (Amman - Jordan, Darul- Bashier for Publishing and Distribution), Second Edition, 1997)

20. O. A. Zaid, Were Islamic records precursors to accounting books based on the Italian method? Accounting Historians Journal 27, 1 (2000)

21. O.A. Zaid, The appointment qualification of Muslim accountants in the Middle Ages. Accounting Education 9, 4 (2000)

22. R. Emerson, Foreword. In Frank H. H. King. The new Malayan nation: a study of communalism and nationalism (New York, Institute of Pacific Relations, 1957)

23. Khoo Kay Kim, Recent Malaysian historiography. Journal of Southeast Asian Studies 10, 2 (1979)

24. Khoo Kay Kim, Recent Malaysian historiography. Journal of Southeast Asian Studies 10, 2 (1979)

25. A. Bhimani, Accounting and the emergence of "economic man". Accounting, Organizations and Society 19, 8 (1994)

26. A. J. Richardson, Corporatism and intraprofessional hegemony: a study of regulation and internal social order. Accounting, Organizations and Society 14, 5 (1989)

27. T. Tinker, A. Koutsoumadi, A mind is a wonderful thing to waste: "think like a commodity", become a CPA. Accounting, Auditing \& Accountability Journal 10, 3 (1997)

28. B. G. Carruthers, Accounting, ambiguity, and the new institutionalism. Accounting, Organizations and Society 20, 4 (1995)

29. Y. Ijiri, A framework for triple-entry bookkeeping. The Accounting Review 61, 4 (1986)

30. W. F. Chua, Teaching and learning only the language of numbers - monolingualism in a multilingual world. Critical Perspectives on Accounting 7, 1 (1996)

31. T. M. Porter, Quantification and the accounting ideal in science. Social studies of Science 22, 4 (1992)

32. K. Robson, Accounting numbers as "inscription": action at a distance and the development of Accounting. Accounting, Organizations and Society 17, 7 (1992)

33. H. Vollmer, How to do more with numbers: Elementary stakes, framing, keying, and the three-dimensional character of numerical signs. Accounting, Organizations and Society 32, 6 (2007)

34. S. Jönsson, Accounting for improvement: Action research on local management support. Accting., Mgmt. \& Info. Tech. 2, 2 (1992)

35. Y. Ijiri, A framework for triple-entry bookkeeping. The Accounting Review 61, 4 (1986)

36. Y. Ijiri, A framework for triple-entry bookkeeping. The Accounting Review 61, 4 (1986) 